\title{
Menata Kawasan Cagar Budaya Berbasis Ekosistem
}

\author{
Oleh \\ Dra. Niken Wirasanti, M.Si \\ Jurusan Arkeologi Fakultas Ilmu Budaya \\ Universitas Gadjah Mada, Yogyakarta
}

\section{Pengantar}

Tidak dapat dipungkiri Indonesia mempunyai kekayaan situs purbakala yang melimpah. Selanjutnya dalam tulisan ini istilah situs purbakala dimasukan dalam katagori cagar budaya yang tidak hanya menampilkan keunikan tinggalan arsitekturnya tetapi juga karakter geofisik sehingga membentuk setting budaya suatu kawasan yang memerlukan perlindungan atau pelestarian. Artinya kawasan tersebut perlu dilindungi karena memiliki komponen-komponen yang bernilai budaya, sehingga memunculkan karakter khas lingkungan budaya (Ikaputra 2000). Dalam Keppres 32/1990 disebutkan definisi Kawasan Cagar Budaya dan Ilmu Pengetahuan adalah kawasan dimana lokasi bangunan hasil budaya manusia yang bernilai tinggi maupun bentukan geologi alami yang khas. Adapun kriterianya adalah berupa tempat serta ruang di sekitar bangunan bernilai budaya tinggi, situs purbakala dan kawasan dengan bentukan geologi tertentu yang mempunyai manfaat untuk me ngembangkan il m u pengetahuan.

Cagar budaya sering keberadaannya menyatu dengan sumberdaya alam (sumbedaya hayati dan sumberdaya non hayati) di suatu kawasan, baik kawasan hutan lindung, kawasan cagar alam ataupun kawasan taman wisata alam. Oleh karena fungsi ketiga kawasan tersebut sebagai perlindungan sistem penyangga kehidupan maka wajib ditetapkan sebagai kawasan konservasi, atau kawasan lindung. Pengertian kawasan konservasi adalah hutan lindung yang merupakan kawasan hutan yang memiliki sifat khas yang mampu memberikan perlindungan kepada kawasan di sekitarnya diantaranya kawasan cagar budaya (Rustiadi, 2009). Contohnya adalah hutan lindung di Dataran Tinggi Dieng Kabupaten Wonosobo dan Kabupaten Banjarnegara) yang di dalamya terdapat kawasan cagar budaya ( Kompleks Candi Dieng), selain itu juga hutan lindung di lereng selatan Gunungapi Ungaran (kabupaten Semarang Jawa Tengah) yang menyatu dengan kompleks Candi Gedongsongo. Kedua kawasan cagar budaya tersebut terintegrasi dengan sumberdaya alam membentuk suatu ekosistem Dataran Tinggi Dieng (kawasan Candi Dieng), ekosistem Gunungapi Ungaran (Kawasan Candi Gedongsongo).

Sebagai suatu ekosistem tergambar hubungan dua arah saling tergantung dan saling pengaruh antara komponen sumberdaya alam (hayati dan non hayati) dan cagar budaya hingga tercapai suatu bentuk keseimbangan. Terjaganya keseimbangan daya dukung lingkungan suatu ekosistem maka terjaga pula kelestarian kawasan cagar budaya, yaitu kompleks candi. Dengan kata lain kondisi kelestarian kawasan cagar budaya dapat dimengerti apabila kawasan tersebut dilihat sebagai suatu sistem yang utuh, yang dikenal dengan ekosistem. Pengertian ekosistem dalam Undang Undang nomer 32 tahun 2009 tentang Perlindungan dan Pengelolaan Lingkungan Hidup, pasal 1 ayat 5 disebutkan ekosistem adalah tatanan unsur lingkungan hidup yang merupakan kesatuan utuh menyeluruh dan saling mempengaruhi dalam membentuk keseimbangan, stabilitas, dan produktivitas lingkungan hidup. Untuk itu pengaturan dan penataan kawasan cagar budaya hendaknya berbasis ekosistem dan dilakukan secara terpadu dengan menata lingkungannya, hingga tercapai berbagai keseimbangan.

Sebagai suatu ekosistem yang utuh, sumberdaya alam dan budaya bersifat dinamis mengalami perubahan dari waktu ke waktu. Artinya dalam ekosistem apabila salah satu komponen tidak berfungsi akan berakibat terganggunya roda dinamika ekosistem, yaitu laju pemanfaatan tidak seimbang dengan laju pemulihan.

Roda dinamika eksistem akan semakin cepat berubah apabila banyak mendapat intervensi manusia. Asumsinya jika salah satu sumberdaya di eksploitasi berlebihan maka akan mengganggu kondisi daya dukung lingkungan dan dapat dipastikan terjadi beragam bencana yang akan mengancam sumberdaya lainnya termasuk kawasan cagar budaya. Keberadaan kompleks Candi Dieng dan Candi Gedongsongo yang menyatu di kawasan hutan lindung tentunya akan terkena imbas apapun yang terjadi di lingkungan tersebut. Apabila hutan beralih fungsi dan tidak sesuai dengan peruntukannya dapat dipastikan terjadi degradasi lingkungan dan daya dukung menjadi labil, sehingga akan berpengaruh pada kelestarian cagar budava, demikian pula sebaliknva. 
Konsep daya dukung (Carrying capacity) berkembang seiring dengan bertambahnya tekanan terhadap sumberdaya dan lingkungan yang disebabkan oleh aktivitas manusia (Rustiadi, 2009; Haryono, 2010).

Upaya melestarikan kawasan cagar budaya yang berbasis ekosistem seringkali dipandang belum mendesak dilakukan. Kegiatan menata kawasan cagar budaya, masih mengesampingkan kondisi ekosistemnya, dan belum mengkaitkan dengan isu-isu program pembangunan lingkungan yang lebih luas, sehingga upaya melestarikan cagar budaya tampak tidak maksimal. Sebagai contoh adalah pengelolaan kompleks Candi Arjuna (Dieng) yang ditata agar menarik tentunya diharapkan kompleks candi akan lestari dan mampu mendongkrak tingkat kunjungan wisatawan. Namun yang terjadi tingkat kunjungan wisata masih terkesan biasa-biasa saja dan belum menunjukkan tingkat kunjungan wisatawan yang signifikan. Pengamatan secara keseluruhan menunjukkan adanya sejumlah masalah lingkungan yaitu hampir $80 \%$ kawasan hutan telah dikonversi menjadi ladang kentang. Kondisi ini berdampak terhadap meningkatnya erosi dan sedimentasi di bagian hilir, rawan longsor, hilangnya keanekaragaman hayati. Ditambah lagi perilaku masyarakat dalam bertani yang menempatkan tumpukan pupuk kandang di sepanjang jalan menuju Dieng sehingga tercium bau yang tidak sedap, termasuk jalan menuju kompleks Candi Arjuna dan Candi Dwarawati. Padahal harapan wisatawan, kawasan Dieng yang berada di ketinggian lebih dari 2000 meter di atas permukaan laut dengan dikelilingi hutan lindung, dibayangkan memiliki udara sejukdingin ditambah dengan panorama wisata alam dan cagar budaya yang menarik.

Kondisi hampir sama terjadi di ekosistem Gunungapi Ungaran, tempat keberadaan kompleks Candi Gedongsongo, menunjukan adanya eksploitasi mataair panas yang dimanfaatkan dalam bentuk kolam pemandian air panas. Fasilitas kolam dan fasilitas pelengkap lainnya berupa kamar mandi, kamar ganti pakaian dan sebuah taman juga pelebaran jalan setapak telah dibangun cukup representatif. Lambat tapi pasti adanya fasilitas-fasilitas wisata yang dibangun di lereng selatan Gunung Ungaran ini akan berpengaruh terhadap kelestarian cagar budaya kompleks Candi Gedongsongo. Bagaimana tidak, karena fasilitas kolam air panas dibangun di lembah antara kompleks Candi III dan kompleks Candi IV. Keberadaan kolam airpanas akan menambah masalah lingkungan di kawasan di lereng Gunungapi Ungaran, juga di sejumlah lereng menunjukan kondisi yang rentan terhadap gerakan massa tanah dan batuan.

Kondisi ekosistem Dataran Tinggi Dieng dan ekosistem Gunungapi Ungaran menunjukkan sejumlah fasilitas yang dibangun dan terjadinya alih fungsi lahan dilakukan tanpa memperhatikăn daya dukung lingkungannya, sehingga dapat diprediksi kawasan tersebut akan menglami degradasi lingkungan. Banyak fakta dari hasil studi yang menunjukkan bahwa terjadinya degradasi lingkungan sering berkaitan dengan adanya kesenjangan pendapatan, tingkat pendidikan yang rendah dan ketidakseimbangan distribusi kekuatan politik (Torras dan Boyce, 1998 dalam Rustiadi. 2009). Untuk itu penataan kompleks candi tidak dibarengi dengan penataan lingkungan sebagai suatu ekosistem, maka sulit untuk mencapai target yang diharapkan yaitu kelestarian fungsi lingkungan, termasuk kelestarian kompleks candi. Disinilah pentingnya kajian arkeologi yang berorientasi spasial sebagai upaya untuk mengelola kawasan cagar budaya secara terpadu dengan lingkungannya. Artinya penataan tata ruang hendaknya diselenggarakan dengan mengintegrasikan berbagai kepentingan yang bersifat lintas sektor, lintas wilayah dan lintas pemangku kepentingan (Budi Supriyanto, 2009).

Saat ini upaya menjaga kelestarian kompleks percandian terkadang masih terfokus pada pemugaran dan menata kompleks candi. Hal ini menunjukkan kegiatan penanganan cagar budaya masih berorientrasi pada problem kerusakan bangunan dan halamannya, tetapi belum menata kompleks candi yang terintregrasi pada pengaturan lingkungan hidup. Padahal keberadaan bangunan candi selalu terkait dengan kondisi ekosistem yang melingkupinya. Dalam konteks melestarikan daya dukung lingkungan suatu ekosistem, kegiatan pengelolaan harus dilakukan secara holistik dan semangat konservasi. Terkait dengan hal itu dalam tulisan ini akan diulas upaya menjaga kelestarian kawasan cagar budaya yang menjadi bagian dari suatu ekosistem. Dalam bahasan kali ini akan disinggung sekilas contoh persoalan lingkungan pada kawasan Candi Dieng yang berada di ekosistem Dataran Tinggi Dieng dan kawasan Candi Gedongsongo yang berada pada eksosistem Gunungapi Ungaran. Kedua candi tersebut berada di kawasan hutan lindung dan saat ini mengalami degradasi lingkungan sehingga berpengaruh pada kelestarian candi. Selain itu akan dibahas cakupan pengertian kawasan konservasi cagar budaya, 
mengidentifikasi kawasan konservasi sebagai suatu sistem dan alternatif menata kawasan cagar budaya.

\section{II. $\mathrm{C}$ a ku pan $\mathrm{K}$ aw a s a Konservasi Cagar Budaya}

Dalam teori-teori pelestarian dikenal beberapa tingkatan mulai dari historic building/landmarks/monument, histortic sites, historic districts, serta historic cities (Setiawan dan Dallen, 1998). Kegiatan konservasi yang diartikan pelestarian hingga saat ini masih ditekankan pada renovasi bangunan, dan benda-benda purbakala, sedangkan kegiatan konservasi untuk sebuah kawasan cagar budaya belum cukup dengan memugar dan menata halaman tetapi harus terintegrasi dengan pengelolaan lingkungan. Pengertian pengelolaan lingkungan seperti disebutkan dalam Undang-Undang 32 tahun 2009 tentang Perlindungan dan Pengelolaan Lingkungan Hidup pasal 1 ayat 2 adalah upaya sistematis dan terpadu yang dilakukan untuk melestarikan fungsi lingkungan hidup dan mencegah terjadinya pencemaran dan atau kerusakan lingkungan hidup yang meliputi perencanaan, pemanfaatan, pengendalian, pemeliharaan, pengawasan, dan penegakan hukum.

Sejumlah disiplin ilmu menggunakan istilah konservasi yang berarti menyelamatkan, melindungi, melestarikan, dan menyimpan. Di bidang arkeologi terdapat perkembangan arti istilah konservasi (Uka Tjandrasasmita, 1995) yang antara lain dapat dirunut dari piagam International (International Charter). International Commission on Monument and site (ICOMOS) tahun 1964, disebutkan pengertian termasuk preservasi harus mempertahankan keadaan aslinya, tidak boleh ada konstruksi baru, penghancuran atau modifikasi yang dapat mengubah hubunganhubungan keseluruhan dan warna. Adapun Restorasi ialah memelihara dan menunjukkan nilai aestetik dan historis monumen didasarkan penilaian bahan asli dan dokumen yang authentik. Dalam perkembangannya (Burra Charter ICOMOS Auatralia 1978, Uka Tjnadrasasmita, 1995, Alpin, 2009) kegiatan konservasi mencakup proses-proses maintenance, preservasition, restoration, reconstruction, adaption yang masing-masing mempunyai definisi. Konservasi merupakan kegiatan melestarikan nilai penting budaya pada suatu place baik situs, areal, dan bangunan atau kelompok bangunan termasuk lingkungannya. Mantenence berarti usaha perlindungan yang terus menerus terhadap semua bahan yang digunakan. Preservasi berarti usaha mempertahankan fabric (semua bahan fisik yang dipakai) dan place sekaligus usaha menahan kerusakan. Adapun restorasi berarti mengembalikan a tau menggabungkan kembali komponen-komponen yang ada tanpa ada penambahkan bahan baru. Rekonstruksi berarti mengembalikan suatu place sedapat mungkin mendekati keadaan awalnya dan tidak boleh dikacaukan oleh penciptaan kembali ataupun rekonstruksi berdasarkan perkiraan. Pengertian konservasi sering ditambah dengan pengertian preservasi yang berarti pengawetan dan pemeliharaan yang satu sama lain tidak dapat dipisahkan. Pengawetan dilakukan tanpa pemeliharaan terasa sia-sia, begitu pula sebaliknya. Konservasi dan preservasi memiliki pengertian yang luas tidak hanya terbatas pada pembersihan dan treatment, tetapi termasuk juga reparasi, pembinaan kembali dan pemugaran. (Soejono 1979 dalam Uka Tjandrasasmita, 1995, ). Lebih tegas disebutkan oleh Samidi dan Ismiyono (1986), dalam mempreservasi monument, kegiatan restorasi tak dapat dipisahkan dengan konservasi. Dengan kata lain restorasi akan berhasil apabila ditunjang oleh upaya-upaya konservasi. Restorasi sukar dipisahkan dengan koservasi, karena restorasi melakukan penangan aspek struktural, dan konservasi penanganan pada aspek pengawetan bangunan.

Dari uraian tersebut pengertian konservasi di bidang arkeologi terkonsentrasi pada upaya penanganan benda purbakala dan bangunannya, dan hal itu masih menjadi porsi utama dalam menjaga kelestarian benda cagar budaya. Meskipun salah satu bagian dalam Charter International sudah menyebutkan pengertian konservasi tidak hanya ditujukan kepada bendanya tetapi juga terhadap lingkungannya, namun kegiatan konservasi dalam skala kawasan belum mendapat perhatian penuh. Padahal dalam buku Petunjuk teknis perlindungan dan Pembinaan Peninggalan Sejarah dan Purbakala (1985) juga sudah disebutkan bahwa konservasi mencakup tindakan-tindakan yang diambil untuk memelihara dan mengawetkan benda-benda peninggalan sejarah dan purbakala agar terhindar dari kerusakan dan pelapukan lebih lanjut. Selain itu disebutkan pula bahwa kegiatan konservasi tidak hanya ditujukan kepada bendanya saja, tetapi juga terhadap lingkungannya agar kondisinya dapat terkendali sehingga membantu langkahlangkah pengawetan.

$$
\text { Pengertian konservasi }
$$

dalam bidang ilmu arsitektur menunjukan perkembangan bahwa konservasi pada awalnva berasal dari 
konsep preservasi yang bersifat statis. Maksudnya, bangunan yang menjadi objek preservasi dipertahankan persis seperti keadaan aslinya. Konsep yang cenderung statis tersebut kemudian berkembang menjadi konsep konservasi yang bersifat dinamis, dengan cakupan yang lebih luas. Sasaran kegiatan konservasi tidak hanya pada benda dan bangunan arkeologis saja tetapi juga kawasannya. Pada akhirnya pengertian konserrvasi menjadi payung dari segenap kegiatan pelestarian lingkungan binaan (budaya) yang meliputi preservasi. restorasi, rehabilitasi, rekonstruksi, adaptasi, dan revitalisasi (Eko Budiarjo, 1997). Pengertian konservasi juga mengacu kesepakatan international yang dirumuskan dakam Piagam Burra tahun 1981. Dalam piagam tersebut konservasi disefinisikan sebagai segenap proses pengelolaan suatu tempat (place) agar makna kultural terpelihara dengan baik. Place diartikan sebagai suatu tapak (site) area, bangunan, dan kelompok bangunan. Adapun makna kultural diartikan sebagai sejumlah nilai (keindahan, kesejarahan dan pengetahuan) yang dapat membangkitkan kenangan orang akan suatu tempat.

Akhir-akhir ini beberapa kegiatan konservasi cagar budaya yang terintegrasi dengan penataan lingkungan sudah mulai diperhatikan, misalnya penelitian pemintakatan kawasan situs Candi Gedongsongo yang dilakukan akhir tahun 2009. Kegiatan dimulai dengan mengidentifikasi isu dan masalah-masalah lingkungan hasil penelitian para ahli yang berkompeten di bidangnya, kemudian masing-masing peneliti momberikan rekomendasi yang akan berguna untuk menyusun master plan.
Kegiatan penelitian tentang kawasan cagar budaya yang berdimensi keruangan sudah cukup banyak ditulis para akademisi dengan menggunakan teori-teori dan konsep dari sejumlah disiplin ilmu yang banyak berkaitan dengan ruang dan waktu. Sebut saja arsitektur, geografi, geologi, dan ilmu lingkungan. Di bidang arsitektur berkembang kajian konservasi kawasan bersejarah, Geografi memiliki kajian kawasan dengan pendekatan spatial, pendekatan ekologikal ataupun pendekatan lingkungan, dan pendekatan regional kompleks (Haggett,1972). Geologi mengembangkan pula sistem pembelajaran yang cakupannya mencari hubungan antara budaya dan lingkungan geologi ( Keller 2000 dalam Sri Mulyaningsih 2010). Adapun Ilmu Lingkungan mengembangkan perspektifperspektif mengenai peran manusia di dalam alam (Tucker,2007; Evans 1999). Dalam dinamika kelingkungan hubungan antara manusia dengan alam terus mengalami perubahan baik pola hubungan, struktur, maupun prosesnya. Disitulah tercermin beragam komponen lingkungan hidup saling berinteraksi dan saling ketergantungan dalam ruang yang mengitarinya, sehingga antara ruang dan komponen lingkungan merupakan suatu kesatuan sistem.

Memahami tata ruang dalam suatu ekosistem adalah penting untuk menata kawasan khususnya kawasan cagar budaya yang akan dikonservasi. Ruang adalah bagian dari alam yang merupakan wadah atau tempat yang di dalamnya terdapat ataupun tidak terdapat, satu atau lebih zat atau materi dan mengalami perubahan. Ruangruang atau seting-seting yang mengelompok dalam suatu sistem dan masing-masing ruang menjadi wadah sumberdaya, maka sistem seting dalam suatu ruang didefinisikan sebagai kawasan (Haryadi, 1995; Dilahur, 1991). Di dalam ruang yang terdiri dari lahan dan atmosfer terdapat berbagai komponen lingkungan hidup menempati dan melakukan proses. Ruang yang merupakan bagian dari alam dapat menimbulkan suatu pertentangan jika tidak diatur dan direncanakan dengan baik dalam penggunaan dan pengembangannya (Ristiadi, 2009). Oleh karena adanya dinamika kehidupan yang terus menerus berubah, maka tata ruang juga selalu bersifat dinamis dari waktu ke waktu.

Menjaga agar dinamika ekosistem tetap pada keseimbangan itu mutlak dilakukan, karena akan berpengaruh pada kelestarian kawasan cagar budaya. Dengan demikian sudah saatnya penelitian atau pelatihan konservasi untuk kawasan cagar budaya digiatkan seperti halnya konservasi untuk benda cagar budaya. Artinya kegiatan konservasi untuk kawasan cagar budaya hendaknya menyatu dengan rencana-rencana program pengelolaan lingkungan. Untuk melaksanakan kegiatan tersebut langkah yang diperlukan adalah pengaturan dan penatan lingkungan, dan perlu partisipasi pelaksana dalam perencanaan dokumen dan partisipasi pemikir dalam pelaksanaan perencanaan. Kegiatan biasanya melibatkan instansi terkait misalnya, instansi Kehutanan, instansi Pertanian, Instansi Balai Pelestarian Peninggalan Purbakala, instansi terkait Energi dan Sumberdaya mineral. Adapun partisipasi pemikir yaitu melibatkan sejumlah peneliti yang berkompeten di bidangnya. Para peneliti ini sesuai dengan kompetensinya akan melakukan pengamatan kondisi fisik (iklim, kemiringan lereng, tanah, batuan, 
sruktur geologi, tata air), biotis (keanekaragaman hayati), dan sosial budaya di wilayah studi. Data tersebut penting untuk bahan analisis potensi suatu wilayah secara utuh. Hasilnya memberi rekomendasi land use planning yang mencakup perencanaan penggunaan lahan dan tata ruang.

Suatu kompleks percandian yang menyatu dengan kawasan sumberdaya alam memiliki karakteristik potensi yang beraneka ragam di masing-masing wilayah, baik potensi sumberdaya hayati maupun non hayati. Saat ini berbagai pihak memiliki kepentingan untuk memanfaatkan potensi sumberdaya alam dengan sejumlah alasan yang berbeda-beda. Beragam kepentingan tersebut tampak pada pola pemanfaatan sumberdaya alam yang akhirnya menjadikan kawasan tersebut rawan terhadap konflik. Bersamaan dengan itu karena laju pemanfaatan sangat intensif hingga akhirnya berpotensi mengalami degradasi lingkungan yaitu suatu kondisi yang tidak memungkinkan sumberdaya alam mampu memulihkan kondisinya secara alami.

Contoh kasus terjadi di kawasan hutan di dataran tinggi Dieng beralih fungsi menjadi lahan kentang, gas panas bumi dieksploitasi menjadi energi pembangkit listrik. Demikian pula halnya di kawasan hutan lindung yang ada di sekeliling kompleks Candi Gedongsongo di ekosistem Gunungapi Ungaran (sisi selatan), telah dibangun sejumlah fasilitas untuk mendukung kegiatan pariwisata. Dapat diprediksi pemanfatan lahan atau mengeksploitasi sumberdaya alam yang cenderung terus meningkat dari waktu ke waktu akan berpengaruh pada fungsi lingkungan hidup. Salah satu yang terkena dampaknya adalah cagar budaya, dan memulihkan kembali rusaknya cagar budaya adalah suatu hal yang tidak mudah dilakukan untuk tidak mengatakan sulit. Untuk itu pilihannya adalah dilakukannya perlindungan kawasan dalam bentuk penataan ruang secara terpadu berbasis ekosistem dengan prinsip dan semangat konservasi. Berbasis ekosistem itu penting karena ruang merupakan komponen eksosistem dimana fungsi-fungsi ekologis dari ruang mempengaruhi kesinambungan dan kontinuitas dari suatu sistem (Rustiadi,2009). Selanjutnya secara spesifik diuraikan, tujuan menata ruang dilakukan sebagai: 1) optimasi pemanfaatan sumberdaya guna terpenuhinya efisiensi dan produktivitas, 2) alat dan wujud distribusi sumberdaya guna terpenuhinya prinsip pemerataan, keberimbangan, dan keadilan. 3) menjaga keberlanjutan pembangunan, 4) menciptakan rasa aman, 5) kenyamanan ruang.

\section{Kawasan Cagar Budaya sebagai ekosistem \\ Ekosistem Dataran Tinggi} Dieng (Kompleks Candi Dieng) dan ekosistem Gunungapi Ungaran (Kompleks Candi Gedongsongo) merupakan contoh ekosistem yang senantiasa berubah dari waktu ke waktu mengikuti proses interaksi berbagai kehidupan di dalamnya juga intervensi dari luar. Itulah yang disebut dinamika ekosistem, adanya sejumlah intervensi manusia dalam kawasan tersebut, maka dapat dibayangkan terjadi proses interaksi yang amat kompleks dalam ekosistem tersebut. Terkait dengan hal itu untuk melakukan penataan suatu kawasan yang akan dikonservasi perlu dikenali cara menganalisis data lapangan, dan salah satunya adalah dengan pendekatan sistem. Sistem didefinisikan sebagai suatu kesatuan dari berbagai komponen/bagian yang saling berinteraksi membentuk suatu fungsi/ tujuan tertentu.

Untuk mengenali dinamika ekosistem yang terjadi di suatu kawasan maka perlu mengenali ciri dari suatu sistem tersebut (Fuad Amzyari, 1995) yaitu: 1) tujuan atau fungsi (system obyectives) yang ingin dicapai oleh suatu sistem yang pada umumnya menggambarkan peran atau tujuan sistem tersebut sebagai suatu kesatuan yang utuh. 2) batas suatu sistem (system boundaries) dapat diartikan dengan menunjukkan batas wilayah atau batas ekologis yang mengitari ekosistem tersebut. 3) komponen suatu sistem (system component) atau subsistem adalah bagian-bagian pokok dalam sistem yang menjadi dasar terbentuknya sistem tersebut, yaitu komponen biotis dan komponen abibiotis. 4) elemen sistem (system element) diasosiasikan dengan bagian sistem yang berperan strategis yaitu bagian mana dari sistem yang amat perlu diperhatikan agar sistem tersebut berfungsi lancar. 5) pengelola sistem (system manager) adalah orang yang mengendalikan dan mengatur mekanisme kerja sustu sistem dengan harapan sistem akan bergerak sesuai dengan fungsi dan tujuannya. 6) lingkungan suatu sistem (system environment) adalah gejala sesuatu yang berada di luar batas sistem yang amat mempengaruhi fungsi atau tujuan sistem, namun berada di luar kontrol pengelola sistem.7) sumberdaya ekosistem (system resources) yang dipakai oleh suatu sistem adalah segala sesuatu yang terpakai untuk menggerakkan aktivitas suatu ekosistem. Secara alamiah sumberdaya ekosistem adalah sinar matahari sebagai penggerak berbagai aktivitas kehidupan dalam ekosistem tersebut.

Dengan mengidentifikasi 
dinamika kawasan konservasi pada suatu ekosistem, misalnya kasus di kawasan Cagar Budaya Dieng dan kawasan Cagar Budaya Gedongsongo, maka diharapkan akan mudah memahami proses perubahan yang sedang terjadi dan memprediksi kemungkinan yang akan terjadi. Langkah selanjutnya yang diperlukan adalah program penataan ruang dalam suatu unit ekosistem berdasarkan satuan lahan. Penggunaan pendekatan satuan lahan dengan dasar pemikiran bahwa pada lahan tampak adanya kompleksitas antar unsur-unsur lingkungan. Artinya keberadaan komponen-komponen sumberdaya dalam suatu ekosistem mencerminkan keterkaitan antara ruang dan lingkungan, juga keterkaitan daya dukung dan sumberdaya yang terkandung dalam ruang. Cakupan pengertian daya dukung meliputi dua komponen yaitu kapasitas penyediaan (supportive capacity) dan kapasitas tampung (assmilative capacity).

\section{Manata Kawasan Konservasi Cagar Budaya}

Kegiatan menata kawasan konservasi pada dasarnya menata ruang terkait dengan upaya memanfaatkan ruang-ruang untuk keperluan yang berbeda-beda sehingga diharapkan kemampuan ruang dalam mendukung kegiatan di dalamnya dapat berkelanjutan. Dengan kata lain menata ruang kawasan konservasi adalah kegiatan mengubah pola dan struktur pemanfaatan ruang dalam wujud zonasi-zonasi berdasarkan sejumlah kriteria di antaranya berdasarkan struktur tanah, batuan, topografi, dan tataair. Selain itu kriteria lainnya adalah kawasan yang berdaya dukung rendah atau sensitif harus digolongkan sebagai kawasan konservasi (kawasan lindung), yaitu kawasan yang ditetapkan dengan fungsi utama melindungi kelestarian fungsi lingkungan yang mencakup kawasan suaka alam, kawasan cagar budaya dan kawasan rawan bencana (Rustiadi,2009).

Dalam proses penataan ruang terdapat filosofi yang harus dipahami yaitu (Rustiadi, 2009); 1) sebagai bagian dari upaya memenuhi kebutuhan masyarakat untuk melakukan perubahan atau upaya untuk mencegah terjadinya perubahan yang tidak diinginkan, 2) menciptakan keseimbangan pemanfaatan sumberdaya di masa sekarang dan masa yang akan datang (pembangunan berkelanjutan), 3) disesuaikan dengan kapasitas pemerintah dan masyarakat untuk $\mathrm{m}$ en $\mathrm{g}$ im plem en $\mathrm{tas}$ i k a perencausaan yang disusun, 4) upaya melakukan perubahan ke arah yang lebih baik secara terencana, 5) sebagai suatu sistem yang meliputi kegiatan perencanaan, implementasi dan pengendalian pemanfaatan ruang, 6) dilakukan jika dikendaki adanya perubahan struktur dan pola pemanfaatan ruang, artinya tidak dilakukan tanpa sebab atau kehendak.

Selain mendasarkan pada filosofis tersebut, kegiatan diawali dengan pemahaman tentang macam-macam komponen lingkungan dan sub komponen pada suatu ekosistem kemudian mengamati interaksi antar komponen untuk dapat memahami mekanisme proses kerja dan dinamika sistem di lokasi penelitian. Dalam kegiatan penataan ruang kawasan dapat dilakukan dengan pendekatan keruangan, dan pendekatan lingkungan. Pendekatan keruangan dilakukan dengan menganalisis eksistensi ruang (space) yang berfungsi sebagai wadah kegiatan manusia, yaitu mengamati bagaimanakah pola sebaran dari situs cagar budaya dan bagaimanakah keterkaitan dengan komponen lingkungan lainnya. Selanjutnya diamati pula perubahan apa saja yang terjadi di lokasi penelitian tersebut. Untuk ekosistem Dataran Tinggi Dieng perubahan alih fungsi lahan menyebabkan tingkat erosi sangat tinggi dan sedimentasi tampak di halaman-halaman sekeliling candi. Adapun untuk ekosistem Gunungapi Ungaran (Kompleks Candi Gedongsongo), tampak ada beberapa lokasi yang rawan longsor/gerakan massa tanah dan atau batuan yang berada dekat kompleks candi. Selanjutnya pendekatan lingkungan untuk mengamati pola hubungan antar lapisan sphera yang ada dalam kesatuan ruang, dengan dasar pemikiran masing-masing sumberdaya memiliki karakter dan potensi yang berbeda-beda di setiap ruangnya.

Untuk memperkuat hasil analisis maka dilakukan pengamatan kenampakan geografis di lokasi penelitian dengan alat bantu ketersediaan peta, foto udara, maupun citra satelit. Alat bantu tersebut diperlukan untuk mengamati sebaran berbagai fenomena di suatu ekosistem yang kemudian dipetakan dalam sejumlah peta tematik. Peta tematik yang biasanya disiapkan adalah, peta satuan batuan, peta tanah, peta tataair, peta satuan bentuklahan, peta kelerengan, peta kesesuaian lahan, peta kemampuan lahan, peta rawan bencana dan peta sebaran candi. Peta-peta tersebut di tumpang susun (overlay) dan menghasilkan peta satuan lahan. Dengan pendekatan satuan lahan tersebut akan tampak ruang-ruang yang mencerminkan gejala keterkaitan antar komponen sumberdaya. Berdasarkan satuan lahan tersebut dapat diketahui berbagai ruang yang relatif sama, tetapi dari segi lingkungan 
mempunyai perbedaan disebabkan oleh sejumlah faktor. Lahan yang memiliki hambatan tinggi direkomensaikan sebagai kawasan lindung, dan sebaliknya dapat dijadikan kawasan budidaya. Hasil penelitian berupa identifikasi permasalahan lingkungan dan sejumlah rekomendasi yang dipakai dasar untuk membuat programprogram rinci sesuai dengan peruntukannya dalam bentuk pola dasar penataan kawasan ekosistem. Berdasarkan pola dasar tersebut disusunlah mintakat (zonasi) arahan pemanfaatan ruang berupa pengaturan penggunaan lahan.

\section{Penutup}

Kegiatan konservasi untuk kawasan cagar budaya dalam suatu ekosistem perlu terus digalakan, karena melestarikan kawasan cagar budaya sama pentingnya dengan melestarikan benda cagar budaya. Itu artinya ke depan konservasi hendaknya berorientasi spasial tidak hanya terfokus pada kegiatan konservasi untuk benda cagar budaya. Dasar pemikirannya cagar budaya sebagai sumberdaya berada di sebuah ruang dan menyatu dengan sumberdaya lainnya dalam suatu bentang fisik (physical landscape). Beragam sumberdaya dalam ekosistem dimanfaatkan oleh manusia untuk melangsungkan kehidupannya, maka sudah semestinya kualitas ruang tetap terjaga keseimbangan daya dukung lingkungannya. Terkait dengan hal tersebut mengkaji suatu kawasan hendaknya dipahami adanya kompleksitas dari komponenkomponen lingkungan yang bersifat dinamis, berubah secara berkesinambungan dari waktu ke waktu, sehingga salah satu upaya mengatur dan mengendalikan pemanfaatan sumberdaya adalah dengan penataan ruang.

Me nat a k w a s n konservasi, termasuk kawasan cagar budaya didasarkan pada strategi yang berorientasi pada pengaturan dan penataan lingkungan berbasis ekosistem dengan asas keterpaduan, kelestarian dan keberlanjutan. Artinya diperlukan pengamatan persoalan lingkungan secara lengkap dari beragam disiplin ilmu.

Asas keterpadukan dalam penataan ruang kawasan cagar budaya berada dalam sebuah payung program pengelolaan lingkungan, dan tentunya terintegrasi dengan berbagai kepentingan yang bersifat lintas sektor ataupun lintas wilayah. Hasil kegiatan penataan ruang konservasi berbentuk zoning berdasarkan daya dukung lingkungan dan kesesuaian lahan. Dengan demikian akan tercapai kualitas ekosistem yang serasi, seimbang, dan selaras, sehingga kawasan cagar budaya pun akan lestari. 囚

\section{Daftar Pustaka}

Alpin Graeme, 2002, Heritage Identification, Conservation, and Mangement, Oxford Univesity Press.

Budi Supriyanto, 2009, Manajemen Tata Ruang, Jakarta, Media Brilian.

Dilahur, 1991, Ruang, Lingkungan dan Wilayah, Suatu Konsep dasar Geografi, Forum Geografi, no9 th V, hlm 1-12

Eko Bidiharjo, 1996, tata Ruang Perkotaan, Bandung : Penerbit Alumni

Rustiadi, 2009, Perencanaan dan Pengembangan Wilayah, Jakarta Yayasan Obor.

Evans,John and Terry (O'Connor, 1999, Environmantal Archaeology, Principles and Methods, Sutton Publishing limited.

Haggett, 1972, Geography A Modern Synthesis, New York :Harper \& Row:
Haryadi, 1995, kemungkinan Penerapan Konsep Sisem $\mathrm{S}$ e $\mathrm{t}$ ing $\mathrm{D}$ a l a $\mathrm{m}$ Penemukenalsan Penataan Ruang Kawasan, Berkala Arkeologi th XV.

Haryono, Paulus, 2010 , Perencanaan Pembangunan Kota dan Perubahan Paradigma, Yogyakarta, Pustaka Pelajar

Keller, Edward A, 2000, Environmental Geology, 8th ed, Pearson Prentice Hall Publ.

Samidi, Ismiyono, 1986, The Restoration of Monument in the Site of Banten, The Ford Foundation Project for the Conservation and Development of site Museum Of Banten, tidak dipublikasikan.

Sri Mulyani, 2010, Pengantar Geologi Lingkungan, Jogyakarta :Jalasutra.

Setiawan an Dallen J. Timothy, 1998, The Potential Use of Existing Urban Management

Frameworok for Heritagr Conservation in Indonesia, Unpublished paper.

Torras, $\mathrm{M}$ an JK Boyce, 1998, Income, Inequality, and Polluyion.

Tucker, Mery Evelyn, 2007, Worldviews and Ecology: Religion, Philosopphy and Environment, New York : Orbis Book.

Uka Tjandrasasmita, 1995, Strategi Pelestarian Benda cagar Budaya Hubungannya dengan Arkeologi, Jakarta : Seminar nasional Metodologi Riset Arkeologi, tidak dipublikasikan. 